\section{Towards ageism}

SiR - There is more to the ethical debate about postmenopausal births than the sanctimony of the British press (Nature $367,2 ; 1994)$ or than you allow. Of course, many of the populist arguments fail by extension. For example, if a 59-year-old woman should not have a child because of the risk of her early death, then what of a mortally ill 29-year-old who wishes nonetheless to conceive naturally? Stressing "what is fair to the child" has been a common theme, but both these circumstances are equally unfair to the child and are ethically equivalent.

It is more arguable whether society has a duty to enable conception by women who are not fertile, or not willing to conceive in the usual way. If society is asked to provide the means to conception, then this 'right' can no longer be consi- dered in isolation, which provokes the real ethical question raised by in vitro fertilization - equity.

The world is quite plainly an inequitable place. It is unrealistic to demand Utopia, but most high-technology medicine increases that inequity. Attempts to prolong by medical means the natural fertility of women while so many in the world have no hope of seeing their naturally born children grow to adulthood is another way of increasing the inequity between the haves and the have-nots. The aim of medicine should be to enable people to live their natural lives as comfortably as possible, not to enable them to have whatever they want, whenever and for as long as they want it.

Neville W. Goodman

University Department

of Anaesthetics.

Southmead Hospital,

Bristol BS10 5NB, UK

\section{Legalizing drugs}

SIR - Most of us involved in research on marijuana agree (with a few vocal exceptions) that it is a relatively safe drug. The comparison in your leading article "Decriminalizing drugs?" (Nature 366, 598 ; 1993) with alcohol seems relevant, and there is some scientific support for this. Perhaps we should give serious consideration to the comments of the Surgeon-General of the United States that the legalization of drugs might lead to a reduction in crime, and not allow emotional reaction and vested interests to carry the day.

Sumner Burstein

Department of Biochemistry,

University of Massachusetts

Medical Center,

55 Lake Avenue North.

Worcester,

Massachusetts 01655, USA

\title{
Appeal to Mitterrand in blood scandal
}

This is the text of the letter sent last week by 97 researchers, physicians and public health workers to the French President, François Mitterrand, asking him to pardon the four physicians convicted last year for their part in the events surrounding the contamination of blood supplies in the mid-1980s with human immunodeficiency virus (HIV):

M. PRESIDENT - A French court has sentenced four doctors for the decisions and the measures that were collectively taken by various authorities in 1985 to stop contamination of haemophiliacs with the AIDS virus. Two of these doctors are in prison. One of them is the director of a major blood transfusion centre, the other a scientist internationally recognized for his contribution to AIDS research.

We, doctors, scientists and public health workers from around the world, some of whom are personally affected by this drama, think that it is our duty to express our feeling of injustice and our concern about the possible consequences of this verdict on public health and biomedical research

The verdict on these doctors was delivered after an unprecedented 'trial by the media'. where sensationalism dominated to the detriment of accuracy, and passionate debate took the place of objective facts. Thus, in the absence of extended scientific expertise punishment was opposed to the uncertainty of scientific knowledge at the time of the facts. We believe that such a verdict is unfair, and an inappropriate way of dealing with suffering born of scientific uncertainty. We also believe that it is deeply unjust to punish a few selected individuals for the lacunae and dysfunctions of our health system as a whole.

Furthermore, this verdict is worrying in that, under the influence of similar outside pressures, it could happen again in other cases involving decisions made on matters at the frontiers of scientific knowledge. Such sentences work against medical progress, because the fear of legal reprisals could then divert doctors and scientists from doing their duty and from taking the responsibilities that are theirs. As a result, medical research and patients woutd be deprived of the valuable contribution of devoted, highly skilled professionals.

The extent of infection of haemophiliacs with the AIDS virus in France is unfortunately analogous to that in other countries where the same therapeutic approaches were used. As in other countries, most contamination cases occurred at the beginning of the 1980 s, when science, medicine and technology were not yet able to prevent them. Throughout the world, thousands of doctors and scientists were involved in the preparation and administration of anti-haemophilic factors, and in most countries undeniable delays occurred in the decision-making processes concerning this particular public health problem at various administrative, technological and clinical levels. Is it reasonable in such circumstances to attribute blame to a few individuals in the face of an almost universal health hazard, which involved so many men and women whose very aims in life are to help and to heal?

Through numerous examples, the history of medicine has taught us that months, and often years, must pass before a scientific discovery is validated, recognized and integrated into the general consciousness. Only then can such discoveries be brought to bear upon decisions concerning public health. Humility, one of the prerequisites of progress, obliges us to recognize that, despite its fantastic evolution, the power of medical science is still less great and less immediate than popular hope and imagination would care to acknowledge. Our public health structures still have a long and arduous path of development and maturation ahead.

While affirming our solidarity and compas- sion for the haemophiliacs and their families stricken by AIDS, it is our duty to guard against any unjustified sentiment of mistrust against doctors and medical science, which would be counterproductive to public health. Thus, it is for the sake of public interest, M. President, that we wish to share our serious concern with you.

We hope that it will be possible for you to use your authority and power justly to appease past and present suffering and to prevent any wrongs that science and indifference might bring about in the future. A first step in this direction would be a presidential pardon.

Maurice Algazl, Rosemary Ancelle-Park, BirgitTa asjo, Francis Barin, Michel Barme, Francolse BarreSinoussi, HenRI Baylon, Joseph Benichou, Gabriel Benichou, ANNIE Bezeaud, ANtoine Blancher, William A. Blattner, Phillippe Blot, Georges Bourroulllou, DaVID BOUTtIER, BERNARd BOVEN, JEAN-BAPTISTE BRUNET, Yves Cadroy, Jacques Caen, Christiane Cahan, Patrick Calvas, Claudine Caranobe, Robin W. Carrell, Michel Chanzy, Gerard Chaouat, Francesca Chiodi, Pierre COlombies, ANTONIO COUTINHO, JEAN DAUSSET, ISABELLE de Vincenti, Patrice Debre, Francolse Denis, Jan Desmyter, VinCENT DEUBEL, AgNes DEVERGIE, ANDRE DODIN, JEAN-FrancoIs DORE, JeAN-CLAUde DrEYFus, Colette Dreyfus-Brisac, Jean Ducos, Herve Durand, Eva Maria Fenyö, HeRve Fleury, JeAn-Jacques Fournel, Jacques Frottier, Jean Gaillard, Pierre Galanaud, Pierre Garcon, louis Gazzolo, alain Jean Georges, Marie-Claude Georges-Courbot, Marc Girard, Eliane Gluckman, Jean Claude Gluckman, Michel Goldberg, Patrick Golbau, Marie-ClaUde Guillin, ANDre Herrault, Myra Jennings, Irene Juhan-Vague, Phyllis J. KankI, MICHEL KaZATCHKINE, ANDRE KIRN, DAVID KLATZMANN, JEAN-PIERRE KOHEN, HENRI KREIS, JACQUES KRUH, LEON LE MINOR, GUY LESOURD, ROSETTE LIDEREAU, PIERRE LORTHOLARY, WILlIAM LOWENSTEIN, JEAN LOYGUE, HERBert MarcoVich, Michel Marty, Christian Mathiot, PhilipPe Monod-Broca, Gerard OrTh, Luiz Pereira da Silva, Georges Peres, Jacques Pillot, Christian PoliCARD, JaCQUeS REYnes, WILly ROZENBAum, Gabriella Scarlatti, Gerard Schaison, Jorg Schupbach, PIERRE Sie, Winston Smilovici, JeAn-Charles SOURnia, Daniel tarantola, armand Tavitian, Alain Tedgui, Pierre Testas, Pierre tiollais, agnes Ullman, Elie Wollman, ALICE Wollman. 